\title{
Improving soil phosphorus availability and yield of Zea mays I. using biochar and compost derived from agro-industrial wastes
}

\author{
Huck Ywih Ch'ng, ${ }^{1,2}$ Ahmed Osumanu Haruna, ${ }^{3,4}$ Nik Muhamad Nik Abdul Majid, ${ }^{4}$ \\ Mohamadu Boyie Jalloh 5 \\ ${ }^{1}$ Faculty of Agro Based Industry, Universiti Malaysia Kelantan Jeli Campus, Jeli, Kelantan; ${ }^{2}$ Institute \\ of Food Security and Sustainable Agriculture (IFSSA), Universiti Malaysia Kelantan Jeli Campus, Jeli, \\ Kelantan; ${ }^{3}$ Department of Crop Science, Faculty of Agriculture and Food Sciences, Universiti Putra \\ Malaysia Bintulu Sarawak Campus, Bintulu, Sarawak; ${ }^{4}$ Institute of Tropical Forestry and Forest Products \\ (INTROP), Universiti Putra Malaysia, Serdang, Selangor; ${ }^{5}$ School of Sustainable Agriculture, Universiti \\ Malaysia Sabah, Kota Kinabalu, Sabah, Malaysia
}

\begin{abstract}
Tropical soils such as Ultisols fix phosphorus (P) because of their characteristically high contents of aluminium and iron. Organic amendments could be used to mitigate P fixation. This study aimed to: i) improve soil $\mathrm{P}$ availability, nutrients uptake, and yield of Zea mays L. using biochar and pineapple leaf residues compost; and ii) determine if the use of biochar and pineapple leaf residues compost could exert a residual effect on $\mathrm{P}$. Two cycles of field trials were carried out and the test crop used was Zea mays L. hybrid F1. At harvest, the plants were harvested, partitioned into leaves and stems, and analysed. Soil samples were also collected and analysed. The results suggest that the soil total P, available $\mathrm{P}$, inorganic $\mathrm{P}$, and organic $\mathrm{P}$ recovered from the treatments with the organic amendments were higher compared with the non-
\end{abstract}

Correspondence: Huck Ywih Ch'ng, Faculty of Agro Based Industry and Institute of Food Security and Sustainable Agriculture (IFSSA), Universiti Malaysia Kelantan Jeli Campus, Locked Bag No. 100, 17600 Jeli, Kelantan, Malaysia.

Tel.: +60178537510. E-mail: huckywih@umk.edu.my

Key words: Acid soils; soil phosphorus fixation; pineapple leaf residues compost; biochar; Zea mays L.

Acknowledgements: the authors would like to thank Malaysia Ministry of Education for financial assistance and Universiti Putra Malaysia for providing research facilities. This research was supported by grant from the Malaysia Fundamental Research Grant Scheme (Grant No.: R/FRGS/A07.00/01459A/001/2016/000370).

Received for publication: 8 September 2017.

Revision received: 5 August 2018.

Accepted for publication: 18 August 2018.

(c) Copyright H.Y. Ch'ng et al., 2019

Licensee PAGEPress, Italy

Italian Journal of Agronomy 2019; 14:1107

doi:10.4081/ija.2019.1107

This article is distributed under the terms of the Creative Commons Attribution Noncommercial License (by-nc 4.0) which permits any noncommercial use, distribution, and reproduction in any medium, provided the original author(s) and source are credited. organic amendments. The availability of soil macro-nutrients in the soils and Zea mays L. yield were higher in the treatments with the organic amendments in the first and second field trials. Amending chemical fertilisers with organic amendments have a larger residual effect than chemical fertilisers only and can be used to ameliorate $\mathrm{P}$ fixation of acid soils to improve maize production on acid soils.

\section{Introduction}

Phosphorus $(\mathrm{P})$ is generally available to crops at soil $\mathrm{pH}$ range of 6 and 7. However, when the $\mathrm{pH}$ of soils is less than $6, \mathrm{P}$ deficiency increases in most crops. Phosphorus deficiency in tropical acid soils such as Ultisols is a particular problem because when the soil $\mathrm{pH}$ is less than 5 , iron $(\mathrm{Fe})$ and aluminium ( $\mathrm{Al}$ ) concentrations are very high and react very quickly with $\mathrm{P}$, creating $\mathrm{Fe}$ or $\mathrm{Al}$ phosphate minerals (Adnan et al., 2003). Ultisols in particular fix $\mathrm{P}$ because of their characteristically high contents of $\mathrm{Al}$ and $\mathrm{Fe}$. The high affinity of $\mathrm{Al}$ and $\mathrm{Fe}$ for $\mathrm{P}$ causes considerable immobilisation of $\mathrm{P}$ from $\mathrm{P}$ containing fertilisers applied to Ultisols. Liming followed by regular application of $\mathrm{P}$ fertilisers such as phosphate rocks and triple superphosphate (TSP) to saturate Al and $\mathrm{Fe}$ ions so as to maintain an adequate supply of plant-available $\mathrm{P}$ (Rahman et al., 2014) are the conventional practices that are used to mitigate $\mathrm{P}$ fixation. Liming in particular is carried out to raise soil $\mathrm{pH}$ to near neutral and to as well saturate $\mathrm{Al}$ and $\mathrm{Fe}$ ions so as to maintain an adequate supply of plant-available P. However, this practice has not been economical (Ch'ng et al., 2015). For example, over-liming (soil pH around 8) causes P fixation by $\mathrm{Ca}$ and also, excessive or unbalanced use of $\mathrm{P}$ fertilisers causes eutrophication of water bodies such as rivers and lakes (not environment friendly) (Rahman et al., 2014).

To mitigate $\mathrm{P}$ fixation in tropical acid soils, organic amendments are used to reduce P sorption sites (Ohno et al., 2007; Ohno and Amirbahma, 2010). Organic amendments have also been used to increase $\mathrm{P}$ uptake and crop growth on $\mathrm{P}$ deficient acid soils (Hue, 1990; Hue et al., 1994). The incorporation of organic amendments in highly weathered soils enhances dissolution of $\mathrm{P}$ fertilisers especially rock phosphate because of the competition between decomposition products of the organic amendments and $\mathrm{P}$ for sorption sites, the release of $\mathrm{H}^{+}$protons or organic acids, and phosphatase enzymes released by the microorganisms in the soil (Guppy et al., 2005). The immediate short-term effects of applied fertilisers are often emphasised to the neglect of residual effects. 
Residual effect of organic amendments on soils refers to the carryover benefit of the application on the succeeding crop. When farming is continued on the same site for several years, residual effects of fertiliser treatments considerably affect the soil chemical properties and consequently crop yield (Enwezor et al., 1989). Akande et al. (2003) reported an increase in soil available $\mathrm{P}$ of between 112 and $115 \%$, and 144 and $153 \%$, respectively for a two year field trial, after applying rock phosphate with poultry manure on okra. Application of manures or composts is able to maintain crop yield level for several years due to their residual effects. This is because the manures or composts tend to release a small, steady amount of nutrients over a course of time (up to several years) for plant uptake (Eghball, 2002).

Nutrients present in organic amendments are not fully available to crops in the season of application (Ramamurthy \& Shivashankar, 1996) because organic amendments tend to release nutrients in small quantity over a course of time. Application of $\mathrm{P}$ fertilisers alone such as TSP will exert little residual effect due to its fast nutrients dissolving process (Rivaie et al., 2008). Amending biochar and compost produced from agro-industrial wastes such as pineapple leaf residues compost could be used to mitigate $P$ fixation by reducing the $\mathrm{P}$ sorption sites. Besides, amending organic amendments with $\mathrm{P}$ fertilise would dissolve the nutrients slowly by releasing it slowly over a course of time, thus exerting a good residual effect. Thus, the objectives of this study were to: i) improve soil $\mathrm{P}$ availability, nutrients uptake, and yield of Zea mays L. using biochar and pineapple leaf residues compost; and ii) determine if the use of biochar and pineapple leaf residues compost could exert a residual effect on $P$.

\section{Materials and methods}

\section{Soil and organic amendments characterisation}

Prior to the field experiment, soil samples (Nyalau Series, Typic Paleudult) were collected at $0-20 \mathrm{~cm}$ using a soil auger. The sampling area was $50 \times 50 \mathrm{~m}$ in which 20 soil samples were randomly taken. The soil samples were air-dried, ground, and sieved to pass through 2-mm sieve. The soil samples were analysed for $\mathrm{pH}$ and electrical conductivity (EC) using $\mathrm{pH}$ meter (Mettler Toled FE20 FiveEasy, USA) and EC meter (Mettler Toled FE20 FiveEasy, USA) (Peech, 1965; Tan, 2003). Soil texture was determined using the hydrometer method (Bouyoucus, 1962; Tan, 2003). Total $\mathrm{C}$ and total $\mathrm{N}$ were determined using a CHNS analyser [TruSpec Micro Elemental Analyser (NCHS), LECO, USA]. Total organic matter was obtained by multiplying the total $\mathrm{C}$ reading with 0.58 (Brady and Weil, 2002). Soil organic C was determined using Walkley and Black method (Tan, 2003). Total P was extracted using aqua regia extractant while available $\mathrm{P}$ was extracted by Mehlich No.1 double acid (Tan, 2003) after which the molybdenum blue method was used to determine the total $\mathrm{P}$ and available $\mathrm{P}$ contents (Tan, 2003; Murphy and Riley, 1962). Afterwards, C/N and $\mathrm{C} / \mathrm{P}$ ratios were calculated. Soil cation exchange capacity (CEC), $\mathrm{K}, \mathrm{Ca}, \mathrm{Mg}, \mathrm{Na}$, and $\mathrm{Fe}$ were extracted using the ammonium acetate method after which $\mathrm{K}, \mathrm{Ca}, \mathrm{Mg}, \mathrm{Na}$, and $\mathrm{Fe}$ were determined using an atomic absorption spectrophotometer (AAS) (PerkinElmer Pin AAcle 900F, USA) (Schollenberger and Dreibelbis, 1945). Exchangeable acidity and Al were determined titrimetrically using $0.01 \mathrm{M} \mathrm{NaOH}$ and $0.01 \mathrm{M} \mathrm{HCl}$ after being extracted by $1 \mathrm{M} \mathrm{KCl}$, respectively as described by Rowell (1994).

The biochar (commercially produced by using chicken litter as feedstock) and compost produced by co-composting of pineapple leaf residues and chicken manure slurry (Ch'ng et al., 2013) were analysed for $\mathrm{pH}$ and $\mathrm{EC}$ (Peech, 1965), total $\mathrm{C}$ and total $\mathrm{N}$ using a CHNS analyser [TruSpec Micro Elemental Analyser (NCHS), LECO, USA]. The dry ashing method (Cottenie, 1980) was used to extract $\mathrm{P}, \mathrm{K}, \mathrm{Ca}, \mathrm{Mg}, \mathrm{Na}, \mathrm{Zn}, \mathrm{Cu}, \mathrm{Fe}$, and $\mathrm{Al}$ from the biochar and compost. The extracts were analysed for $\mathrm{K}, \mathrm{Ca}, \mathrm{Mg}, \mathrm{Na}, \mathrm{Zn}, \mathrm{Cu}$, $\mathrm{Fe}$, and Al using AAS (PerkinElmer Pin AAcle 900F, USA) whereas $\mathrm{P}$ was determined using the molybdenum blue method (Murphy and Riley, 1962; Tan, 2003). $\mathrm{C} / \mathrm{N}$ and $\mathrm{C} / \mathrm{P}$ ratios of the soil, biochar, and compost were calculated using the total $\mathrm{C}, \mathrm{N}$, and $\mathrm{P}$ determined.

\section{Evaluation of treatments effects on selected soil chemi- cal properties and soil $P$ fractions in the first field trial}

A field trial was conducted at Universiti Putra Malaysia Bintulu Sarawak Campus, Malaysia. The test crop used in this study was Zea mays L. hybrid F1. Before planting, weeds were removed by spraying glyphosate herbicide after which they were slashed and removed manually. After that, the plot was ploughed and harrowed. A total of 12 beds (plots) were prepared. The size of each plot was $2.4 \mathrm{~m}$ (length) $\times 2.4 \mathrm{~m}$ (width). Fifteen plants were planted on each plot with spacing of $80 \mathrm{~cm}$ between rows and 40 $\mathrm{cm}$ between plants. The distance between the beds within a row was $1 \mathrm{~m}$ whereas the distance between rows was $2 \mathrm{~m}$. The field experiment was conducted in a randomised complete block design with three blocks. The compost and biochar were applied at $300 \mathrm{~g}$ plant ${ }^{-1}$ based on the findings in our previous greenhouse study (Ch'ng et al., 2014). Urea $(46 \% \mathrm{~N})$, TSP $\left(46 \% \mathrm{P}_{2} \mathrm{O}_{5}\right)$, and muriate of potash (MOP) $\left(60 \% \mathrm{~K}_{2} \mathrm{O}\right)$ were applied at $60 \mathrm{~kg} \mathrm{~N} \mathrm{ha}^{-1}, 60 \mathrm{~kg}$ $\mathrm{P}_{2} \mathrm{O}_{5} \mathrm{ha}^{-1}$, and $40 \mathrm{~kg} \mathrm{~K}_{2} \mathrm{O} \mathrm{ha}^{-1}$, respectively. These rates were based on the recommendation of the Malaysia Agricultural Research and Development Institute (MARDI, 1993). The fertilisers were applied in two equal splits i.e., at 10 and 28 days after sowing (DAS). Although this is not practical in the real planting situation, however, to assess the performance of organic amendments influencing $\mathrm{P}$ availability in soil, this approach was adopted in this study. The treatments are listed as below (Table 1).

At harvest (75 DAS), the plants were harvested and partitioned into leaves and stems. The plant parts were oven dried at $60^{\circ} \mathrm{C}$ in an oven until constant weight was attained after which their dry weight were determined using a digital balance (Sartorius ENTRIS124-1S Lab Balance, Germany). Soil samples were collected using a mineral soil auger, air-dried, crushed, and sieved to pass through a 2-mm sieve, analysed for $\mathrm{pH}, \mathrm{EC}, \mathrm{CEC}$, exchangeable acidity, total $\mathrm{N}$, total $\mathrm{C}$, organic $\mathrm{C}$, total $\mathrm{P}$, available $\mathrm{P}$, and cations ( $\mathrm{K}, \mathrm{Ca}, \mathrm{Mg}, \mathrm{Na}, \mathrm{Al}$, and $\mathrm{Fe}$ ) using the methods cited previously. Soil base saturation was calculated by dividing the total amount of basic cations that occupy the cation exchange sites by the total cation exchange capacity. To understand the mechanisms responsible for $\mathrm{P}$ sorption after application of biochar and compost, the soil samples were analysed for $\mathrm{P}$ fractions using Kuo (1996) procedure as listed in Table 2 was followed.

The single dry ashing method (Cottenie, 1980) was used to extract $\mathrm{P}, \mathrm{K}, \mathrm{Ca}, \mathrm{Mg}, \mathrm{Na}, \mathrm{Fe}$, and $\mathrm{Al}$ in the plant parts (leaves and stems). The filtrates were analysed for $\mathrm{K}, \mathrm{Ca}, \mathrm{Mg}, \mathrm{Na}, \mathrm{Al}$, and $\mathrm{Fe}$ using AAS. Phosphorus was determined using the molybdenum blue method (Murphy and Riley, 1962; Tan, 2003). Total N was determined using a CHNS analyser (TruSpec Micro Elemental Analyser (NCHS), LECO, USA). The concentrations of N, P, K, $\mathrm{Ca}, \mathrm{Mg}, \mathrm{Na}, \mathrm{Fe}$, and $\mathrm{Al}$ in leaves and stems were multiplied by the respective dry weight of the plant parts to obtain the amounts of $\mathrm{N}$, 
$\mathrm{P}, \mathrm{K}, \mathrm{Ca}, \mathrm{Mg}, \mathrm{Na}, \mathrm{Fe}$, and $\mathrm{Al}$ uptake by the maize plants. Cobs were harvested and weighed to determine the total yield for each treatment. Five cobs were then selected from each treatment for grain count. Phosphorus agronomic efficiency was calculated to determine the yield of crop increase per unit of nutrient applied. Phosphorus agronomic efficiency as defined by Snyder and Bruulsema (2007) below:

Phosphorus agronomic efficiency $\left(\mathrm{kg} \mathrm{ha}^{-1}\right)=\left(\mathrm{Y}_{\mathrm{F}}-\mathrm{Y}_{\mathrm{o}}\right) / \mathrm{F}$

where $\mathrm{Y}_{\mathrm{F}}$ indicates the yield under fertilised treatment $\left(\mathrm{kg} \mathrm{ha}^{-1}\right) ; \mathrm{Y}_{\mathrm{o}}$ indicates the yield under unfertilised treatment $\left(\mathrm{kg} \mathrm{ha}^{-1}\right)$; and $\mathrm{F}$ indicates the rate of $\mathrm{P}$ applied in that particular treatment $\left(\mathrm{kg} \mathrm{ha}^{-1}\right)$.

\section{Evaluation of treatments residual effects on selected soil chemical properties and soil $P$ fractions in the sec- ond field trial}

After harvesting the leaves, stems, cobs, and collecting the soil samples from the first field trial for laboratory analyses, a second field trial was carried out. In this second field trial, the residual effect of the $\mathrm{P}$ fertilisers in the soil was assessed. Hence, only $\mathrm{N}$ (urea) and K (MOP) fertilisers were applied per plant basis in two equal splits at 10 and 28 DAS. A total of 15 maize plants were planted on each plot. At harvest (85 DAS), the leaves and stems of the maize plants were harvested for plant nutrient analyses and nutrients uptake (N, P, K, Ca, Mg, Na, Fe, and $\mathrm{Al}$ ) determination while soil samples were also collected for $\mathrm{pH}$, EC, CEC, exchangeable acidity, total $\mathrm{N}$, total $\mathrm{C}$, organic $\mathrm{C}$, total $\mathrm{P}$, available $\mathrm{P}$, and cations ( $\mathrm{K}, \mathrm{Ca}, \mathrm{Mg}, \mathrm{Na}, \mathrm{Al}$, and $\mathrm{Fe}$ ) determination. Cobs were harvested to determine the total yield and grain count.

\section{Statistical analysis}

Statistical analysis of data such as analysis of variance (ANOVA) and comparisons of means was performed using SAS program version 9.2 (SAS Institute, 2002). The comparison of means was carried out using Tukey's HSD tests at $\mathrm{P}<0.05$.

\section{Results and discussion}

\section{Characteristics of soil and organic amendments}

The selected physico-chemical properties of Nyalau Series (Typic Paleudult) are presented in Table 3. The soil was a sandy loam with a $\mathrm{pH} 4.29$. The soil showed relatively high concentrations of $\mathrm{Al}$ and $\mathrm{Fe}$ due to low soil $\mathrm{pH}$. The $\mathrm{C} / \mathrm{N}$ and $\mathrm{C} / \mathrm{P}$ ratios of the soil were 9.85 and 290.55 , respectively. The high $\mathrm{C} / \mathrm{P}$ ratio suggests the possibility of $\mathrm{P}$ immobilisation in the soil (Morais and Gatiboni, 2015). The biochar analysis shows that it was higher in $\mathrm{pH}(8.5)$, EC (15.5 $\left.\mathrm{dS} \mathrm{m}^{-1}\right), \mathrm{C}(63.27 \%), \mathrm{N}(2.8 \%), \mathrm{P}$ (2.6\%), K (3.9\%), Ca (5.9\%), Zn (85.6 mg kg-1), and Cu (167 mg $\mathrm{kg}^{-1}$ ) whereas $\mathrm{Mg}\left(15.2 \mathrm{~g} \mathrm{~kg}^{-1}\right), \mathrm{Na}\left(19.5 \mathrm{~g} \mathrm{~kg}^{-1}\right), \mathrm{Fe}(5.6 \mathrm{mg} \mathrm{kg}$ $\left.{ }^{1}\right)$, and $\mathrm{Al}\left(0.6 \mathrm{mg} \mathrm{kg}^{-1}\right)$ were lower in the biochar compared to the compost (Table 4). The $\mathrm{C} / \mathrm{N}$ ratios of the biochar and pineapple leaf residues compost were 22.75 and 19.91, respectively whereas their $\mathrm{C} / \mathrm{P}$ ratios were 24.50 and 99.56, respectively (Table 4). These low ratios of biochar and pineapple leaf residues compost suggest net mineralisation of the organic amendments (Neill et al., 1997).

Table 1. Experimental treatments evaluated in the field trials.

\begin{tabular}{|c|c|}
\hline Treatment & Description \\
\hline T0 & $\begin{array}{l}\text { Soil only } \\
\text { (Serves as a negative control, without any application of Urea, TSP, MOP, and Biochar) }\end{array}$ \\
\hline $\mathrm{Tl}$ & $\begin{array}{l}\text { Soil }+5 \mathrm{~g} \text { Urea }+5 \mathrm{~g} \text { TSP }+2.58 \mathrm{~g} \text { MOP } \\
\text { [Serves as a positive control, application of chemical fertilisers (Urea, TSP, and MOP) only without any Biochar or Pineapple leaf } \\
\text { residues compost] }\end{array}$ \\
\hline T2 & $\begin{array}{l}\text { Soil }+5 \mathrm{~g} \text { Urea }+5 \mathrm{~g} \text { TSP }+2.58 \mathrm{~g} \text { MOP }+300 \mathrm{~g} \text { Biochar } \\
\text { (Application of chemical fertilisers (Urea, TSP, and MOP) with Biochar to evaluate the potential of Biochar in improving the soil P } \\
\text { availability provided by TSP) }\end{array}$ \\
\hline T3 & $\begin{array}{l}\text { Soil }+5 \mathrm{~g} \text { Urea }+5 \mathrm{~g} \text { TSP }+2.58 \mathrm{~g} \text { MOP }+300 \mathrm{~g} \text { Pineapple leaf residues compost } \\
\text { (Application of chemical fertilisers (Urea, TSP, and MOP) with Pineapple leaf residues compost to evaluate the potential of pineapple } \\
\text { leaf residues compost in improving the soil P availability provided by TSP) }\end{array}$ \\
\hline
\end{tabular}

Table 2. Sequential fractionation scheme (Kuo, 1996).

\begin{tabular}{|c|c|c|c|}
\hline Extractants & Equilibration & Washing & P fraction \\
\hline $1 \mathrm{M} \mathrm{NH}_{4} \mathrm{Cl}$ & $30 \mathrm{~min}$ & None & Soluble Pi \\
\hline $0.5 \mathrm{M} \mathrm{NH}_{4} \mathrm{~F}(\mathrm{pH} 8.2)$ & $1 \mathrm{~h}$ & Saturated $\mathrm{NaCl}$ & $\mathrm{Al}-\mathrm{Pi}$ \\
\hline $0.1 \mathrm{M} \mathrm{NaOH}$ & $17 \mathrm{~h}$ & Saturated $\mathrm{NaCl}$ & Fe-Pi \\
\hline $\begin{array}{l}0.3 \mathrm{M} \mathrm{Na}_{3} \mathrm{C}_{6} \mathrm{H}_{5} \mathrm{O}_{7} \cdot \mathrm{H}_{2} \mathrm{O}+5 \mathrm{~mL} \text { of } \mathrm{NaHCO}_{3} \\
+1 \mathrm{~g} \text { of } \mathrm{Na}_{2} \mathrm{~S}_{2} \mathrm{O}_{4}\end{array}$ & $\begin{array}{l}\text { Shake } 15 \text { min, preheat } 15 \mathrm{~min} \\
\text { in water bath at } 85^{\circ} \mathrm{C}\end{array}$ & Saturated $\mathrm{NaCl}$ & Reductant soluble-Pi \\
\hline $0.25 \mathrm{M} \mathrm{H}_{2} \mathrm{SO}_{4}$ & $1 \mathrm{~h}$ & Saturated $\mathrm{NaCl}$ & Ca-Pi \\
\hline
\end{tabular}

TSP, triple superphosphate; MOP, muriate of potash. 


\section{Selected soil chemical properties and $P$ availability after first and second field trials}

The $\mathrm{pH}$ of the soils with organic amendments (T2 - soil $+5 \mathrm{~g}$ Urea +5 g TSP +2.58 g MOP +300 g Biochar and T3 - soil +5 g Urea +5 g TSP +2.58 g MOP +300 g Pineapple leaf residues compost) increased significantly by $23.7 \%$ compared with the treatments without organic amendments (T0 - soil only without any fertiliser and organic amendment and $\mathrm{T} 1-$ soil $+5 \mathrm{~g}$ Urea +5 $\mathrm{g}$ TSP $+2.58 \mathrm{~g} \mathrm{MOP}$ ) at the end of first field trial (75 DAS) (Table 5). This was due to the initial $\mathrm{pH}$ and basic cations such as $\mathrm{K}, \mathrm{Ca}$, $\mathrm{Mg}$, and $\mathrm{Na}$ of the organic amendments (Ch'ng et al., 2015). The rapid proton $\left(\mathrm{H}^{+}\right)$exchange between the soil and the organic amendments used in this study also contributed to the increase of the soil $\mathrm{pH}$ (Wong et al., 1998; Tang et al., 1999). The increase in the soil $\mathrm{pH}$ also relates to further decomposition of the organic amendments and this might have further solubilised the inherent $\mathrm{K}$, $\mathrm{Ca}, \mathrm{Mg}$, and $\mathrm{Na}$ contents of the organic amendments to the soil, thus the increases in soil $\mathrm{pH}$. Formation of phenolic, humic-like materials during the initial decomposition of the organic amendments (Narambuye and Haynes, 2006) leads to formation of organic anions, which consume protons in the soil, thus causing soil $\mathrm{pH}$ to increase (Haynes and Mokolobate, 2001). Besides, the release of $\mathrm{OH}^{-}$due to specific adsorption of humic material and organic acids produced by the biochar and pineapple leaf residues compost onto the hydrous surfaces of $\mathrm{Al}$ and $\mathrm{Fe}$ oxides by ligand exchange also responsible for the increased in soil $\mathrm{pH}$ (Hue et al., 1986). The organic amendments (T2 and T3) showed higher soil pH in the second field trial (85 DAS) (Table 6) because of the further release of basic cations such as $\mathrm{K}, \mathrm{Ca}, \mathrm{Mg}$, and $\mathrm{Na}$ from the biochar and pineapple leaf residues compost.

At 75 DAS and 85 DAS, T2 (N-P-K amended with biochar) and T3 (N-P-K amended with pineapple leaves compost) reduced exchangeable acidity, exchangeable $\mathrm{Al}$, and extractable Fe compared with T0 (soil only) and T1 (fertilisers) (Tables 5 and 6). Soil exchangeable $\mathrm{Al}$ was negligible in the soils with the organic amendments (T2 and T3) (Tables 5 and 6). The decrease in soil exchangeable acidity, exchangeable $\mathrm{Al}$, and extractable Fe partly is related to the increase in soil $\mathrm{pH}$. Several authors have reported increase in soil $\mathrm{pH}$ as exchangeable $\mathrm{Al}$ decreases (Noble et al., 1996; Narambuye and Haynes, 2006; Opala et al., 2012). As the soil $\mathrm{pH}$ increased, exchangeable and soluble $\mathrm{Al}$ and Fe precipitated as insoluble $\mathrm{Al}$ and $\mathrm{Fe}$ hydroxides on the negatively charged functional groups of the organic amendments' surfaces. This reaction normally decreases Al and Fe contents in soil (Ritchie, 1994).
Table 3. Selected physico-chemical properties of Nyalau.

\begin{tabular}{lc} 
Property & Value obtained \\
Bulk density $\left(\mathrm{g} \mathrm{cm}^{-3}\right)$ & 1.25 \\
Soil texture & $\begin{array}{c}\text { Sand: } 69.5 \% \text { Silt: } 13.5 \% \\
\text { Clay: } 17 \% \rightarrow \text { Sandy loam }\end{array}$ \\
\hline $\mathrm{pH}$ (water) & 4.29 \\
Total organic matter (\%) & 5.78 \\
\hline Total C (\%) & 3.35 \\
Total N (\%) & 0.34 \\
\hline Total P (ppm) & 115.3 \\
Available P (ppm) & 4.2 \\
\hline C/N ratio & 9.85 \\
C/P ratio & 290.5 \\
\hline CEC (cmol kg-1) & 4.5 \\
Exchangeable acidity $\left(\mathrm{cmol} \mathrm{kg}^{-1}\right)$ & 1.2 \\
\hline Exchangeable Al $\left(\mathrm{cmol} \mathrm{kg}{ }^{-1}\right)$ & 0.75 \\
Exchangeable K (ppm) & 41.16 \\
\hline Exchangeable Ca (ppm) & 170.3 \\
Exchangeable Mg (ppm) & 53 \\
\hline Extractable Fe (ppm) & 120.6 \\
\hline CEC, cation exchange capacity. &
\end{tabular}

Table 4. Selected chemical properties of chicken litter biochar and pineapple leaves residues compost.

\begin{tabular}{lcc}
\hline Property & $\begin{array}{c}\text { Pineapple leaf } \\
\text { residues compost }\end{array}$ & $\begin{array}{c}\text { Chicken litter } \\
\text { biochar }\end{array}$ \\
$\mathrm{pH}$ & 7.89 & 8.5 \\
Electrical conductivity $\left(\mathrm{dS} \mathrm{m}^{-1}\right)$ & 6.9 & 15.5 \\
\hline Total carbon (\%) & 45.8 & 63.7 \\
Total $\mathrm{N}(\%)$ & 2.3 & 2.8 \\
\hline Total P (\%) & 0.46 & 2.6 \\
C/N ratio & 19.91 & 22.75 \\
\hline C/P ratio & 99.56 & 24.5 \\
Total $\mathrm{K}(\%)$ & 2.67 & 3.9 \\
\hline Total $\mathrm{Ca}(\%)$ & 0.4 & 5.9 \\
Total $\mathrm{Mg}\left(\mathrm{g} \mathrm{kg}^{-1}\right)$ & 6,365 & 15.2 \\
\hline Total $\mathrm{Na}\left(\mathrm{g} \mathrm{kg}^{-1}\right)$ & 1,143 & 19.5 \\
Total $\mathrm{Zn}\left(\mathrm{mg} \mathrm{kg}^{-1}\right)$ & 119 & 856 \\
\hline Total $\mathrm{Cu}\left(\mathrm{mg} \mathrm{kg}^{-1}\right)$ & 47.2 & 167 \\
Total Fe $\left(\mathrm{mg} \mathrm{kg}^{-1}\right)$ & 5,062 & 5.6 \\
\hline Total Al $\left(\mathrm{mg} \mathrm{kg}^{-1}\right)$ & 1.5 & 0.6 \\
\hline
\end{tabular}

Table 5. Effect of treatments on selected soil chemical properties in the first field trial.

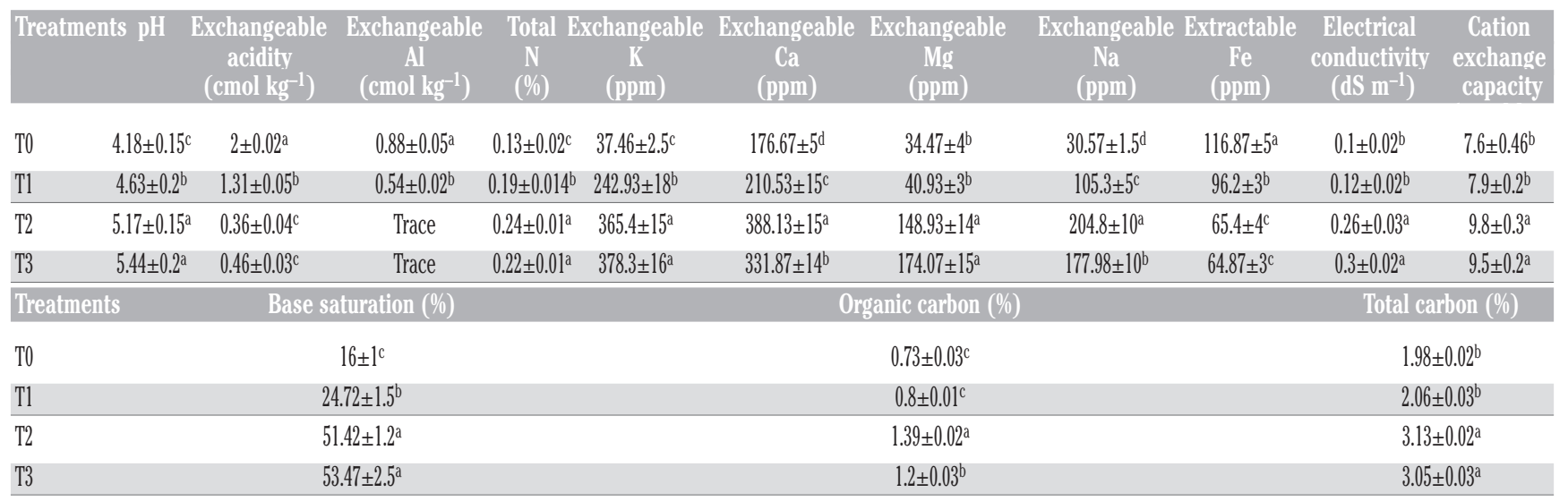

a-fMeans within column with different letter(s) indicate significant difference between treatments by Tukey's HSD test at $\mathrm{P} \leq 0.05$. Columns represent the mean values \pm standard error. 
The soil total $\mathrm{N}$ in T2 (N-P-K amended with biochar) and T3 (N-P-K amended with pineapple leaves compost) was significantly higher compared to T1 (fertilisers) at 75 DAS (Table 5). Similar observation was made for soil exchangeable K (Table 5). The significant higher soil total $\mathrm{N}$ in $\mathrm{T} 2$ and $\mathrm{T} 3$ was because of the higher affinity of the organic amendments for $\mathrm{NO}_{3}{ }^{-}$and $\mathrm{NH}_{4}{ }^{+}$ (Yazdanpanah, 2013). The inherent $\mathrm{N}$ contents of the biochar and compost might have contributed to the increase of total $\mathrm{N}$ in the soil as studies had revealed that biochar and compost effectively reduced the contents of $\mathrm{NO}_{3}{ }^{-}$and $\mathrm{NH}_{4}{ }^{+}$in leachates by 34 and 34.7\%, respectively (Paulin and Malley, 2008; Yao et al., 2012). The residual effects of $\mathrm{N}$ and $\mathrm{K}$ in the second field trial were not significant (Table 6) because urea and MOP were applied during the second field trial except $\mathrm{P}$ fertiliser.

The treatments with organic amendments (T2 and T3) increased soil exchangeable $\mathrm{Ca}, \mathrm{Mg}, \mathrm{Na}$ concentrations, and $\mathrm{EC}$ (Tables 5 and 6) compared with the treatments without the organic amendments (T0 and T1) at the end of first and second field trials. In this study, the EC were within the standard threshold, which is between 0-4 $\mathrm{dS} \mathrm{m}^{-1}$ (Bauder and Brock, 2001). The significant increase in the soil EC (from 0.1 to $0.26 \mathrm{dS} \mathrm{m}^{-1}$ ) was due to the high content of $\mathrm{Na}$ in the organic amendments. This finding is consistent with the significant increase in soil exchangeable $\mathrm{Na}$ at 75 DAS (Table 5). Although the biochar and pineapple leaf residues compost had a relative high EC value of 15.5 and $6.9 \mathrm{dS} \mathrm{m}^{-1}$, respectively), there was no drastic increase in the soil EC. This could be due to the high sorption capacity of ions (low degree of desorption) on the surface of the organic amendments especially the biochar. Application of biochar and compost also increased soil CEC, base saturation, soil organic $\mathrm{C}$, and total $\mathrm{C}$ (Tables 5 and 6) at the end of first and second field trials. The CEC increased because the biochar and compost in this study were mixed with the soil and this might have enhanced decomposition of these organic amendments to release more humic substances, which are known for increasing soil CEC. This result agrees with that of Novak et al. (2009) who also reported a rapid CEC response with fully incorporated biochar amendments in soils (Blackwell et al., 2009). The high base saturation is related to the high basic cations retention due to increase in soil CEC after addition of biochar and compost to the soil. Additionally, the use of biochar and compost also resulted in significant increase in soil organic $\mathrm{C}$ and total $\mathrm{C}$. These results are in agreement with those of Meeuwissen (1992) and Kaschl et al. (2002) who also found positive correlation between the addition of compost and soil organic $\mathrm{C}$ contents.

At the end of first field trial, treatments with the organic amendments (T2 and T3) increased total $\mathrm{P}$ and available $\mathrm{P}$ concentrations compared with the non-organic amendments (T0 and T1) (Table 7). As a result of the increase in the soil $\mathrm{pH}$ at $75 \mathrm{DAS}$, the negative charges on the surface area of organic amendments increased, thus the increased affinity for $\mathrm{Al}$ and $\mathrm{Fe}$ ions instead of $\mathrm{P}$. This led to the increase in the soil total $\mathrm{P}$ and available $\mathrm{P}$ concentrations. An increase in the soil $\mathrm{pH}$ under $\mathrm{T} 2$ and $\mathrm{T} 3$ (Table 5) generally favours $\mathrm{P}$ mobilisation and could also stimulate the mineralisation of organic $\mathrm{P}$, which is a part of the components in total $\mathrm{P}$, thus increased the

Table 6. Effect of treatments on selected soil chemical properties in the second field trial.

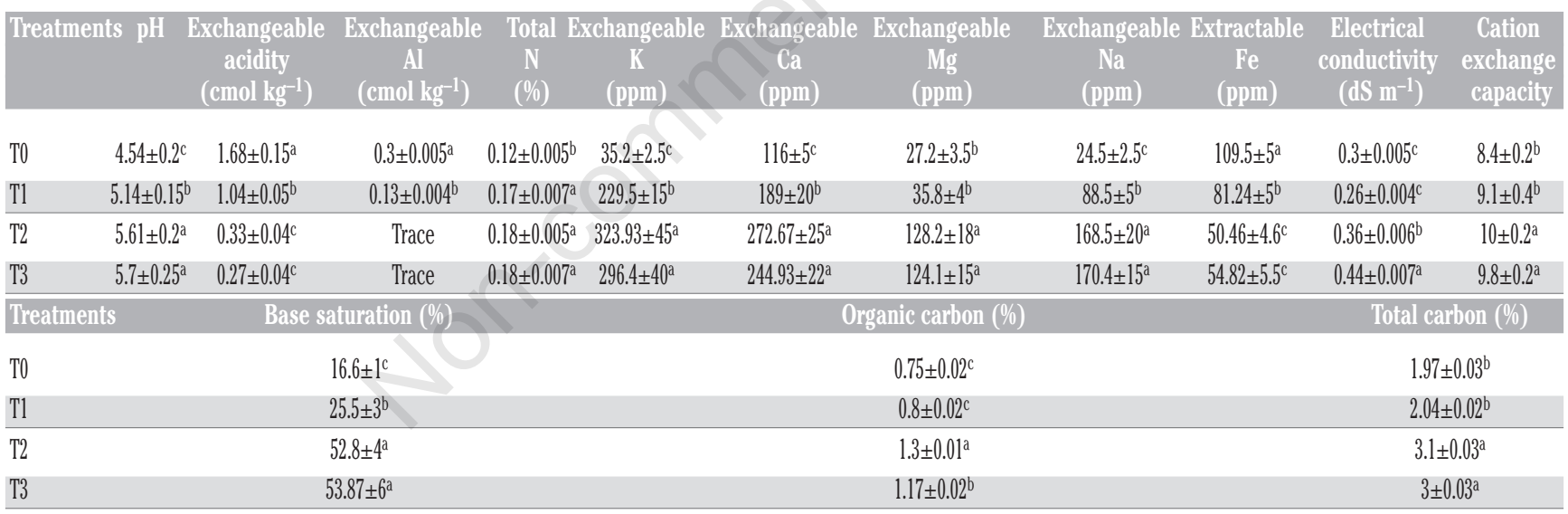

${ }^{\mathrm{a}-\mathrm{e}}$ Means within column with different letter(s) indicate significant difference between treatments by Tukey's HSD test at $\mathrm{P} \leq 0.05$. Columns represent the mean values \pm standard error.

Table 7. Effect of treatments on soil $P$ fractions in the two field trials.

\begin{tabular}{|c|c|c|c|c|c|c|c|c|}
\hline Treatments & Total P & Available P & Soluble-P $P_{i}$ & $\mathrm{Al}-\mathrm{P}_{i}$ & Fe-Pi & Reductant soluble-P $P_{i}$ & $\mathrm{Ca}-\mathrm{P}_{i}$ & Total $P_{o}$ \\
\hline \multicolumn{9}{|l|}{ First field trial (75 DAS) } \\
\hline T0 & $85.2 \pm 3^{\mathrm{c}}$ & $28.2 \pm 1.5^{\mathrm{c}}$ & $7.4 \pm 1.2^{\mathrm{c}}$ & $4.2 \pm 1.2^{\mathrm{c}}$ & $3.2 \pm 0.5^{\mathrm{c}}$ & $1.05 \pm 0.1^{\mathrm{c}}$ & $2 \pm 0.2^{c}$ & $67.55 \pm 4^{c}$ \\
\hline $\mathrm{T} 1$ & $3329.2 \pm 160^{\mathrm{b}}$ & $618 \pm 20^{\mathrm{b}}$ & $550.75 \pm 15^{\mathrm{b}}$ & $700.5 \pm 35^{\mathrm{a}}$ & $480.3 \pm 60^{a}$ & $175.2 \pm 20^{\mathrm{a}}$ & $215.3 \pm 25^{b}$ & $1207.15 \pm 140^{b}$ \\
\hline T2 & $3911.5 \pm 150^{a}$ & $1189 \pm 125^{\mathrm{a}}$ & $692.9 \pm 50^{\mathrm{a}}$ & $530.5 \pm 70^{b}$ & $389.2 \pm 35^{b}$ & $106.5 \pm 10^{b}$ & $275.5 \pm 20^{\mathrm{a}}$ & $1916.9 \pm 150^{\mathrm{a}}$ \\
\hline $\mathrm{T} 3$ & $3850.4 \pm 160^{\mathrm{a}}$ & $1091.1 \pm 125^{\mathrm{a}}$ & $650.1 \pm 60^{\mathrm{a}}$ & $560.4 \pm 60^{\mathrm{b}}$ & $396.7 \pm 30^{\mathrm{b}}$ & $109.1 \pm 12^{b}$ & $228.7 \pm 10^{b}$ & $1905.4 \pm 155^{\mathrm{a}}$ \\
\hline \multicolumn{9}{|l|}{ Second field trial (85 DAS) } \\
\hline T0 & $76.95 \pm 4^{c}$ & $15.13 \pm 2^{d}$ & $3.5 \pm 1^{\mathrm{c}}$ & $5.4 \pm 1.5^{\mathrm{c}}$ & $4.1 \pm 1^{c}$ & $1.3 \pm 0.1^{c}$ & $2.5 \pm 1^{\mathrm{c}}$ & $60.15 \pm 5^{c}$ \\
\hline $\mathrm{T} 1$ & $1866.8 \pm 150^{\mathrm{b}}$ & $509 \pm 10^{c}$ & $236.5 \pm 24^{b}$ & $650.8 \pm 40^{\mathrm{a}}$ & $450.8 \pm 30^{\mathrm{a}}$ & $150.9 \pm 15^{a}$ & $230.5 \pm 15^{b}$ & $147.8 \pm 35^{\mathrm{b}}$ \\
\hline $\mathrm{T} 2$ & $3009.5 \pm 160^{\mathrm{a}}$ & $610.7 \pm 25^{\mathrm{a}}$ & $380.6 \pm 25^{\mathrm{a}}$ & $512.2 \pm 35^{b}$ & $369.1 \pm 25^{b}$ & $98.9 \pm 5^{b}$ & $294.7 \pm 25^{\mathrm{a}}$ & $1354.5 \pm 135^{\mathrm{a}}$ \\
\hline $\mathrm{T} 3$ & $2793.7 \pm 140^{\mathrm{a}}$ & $550.8 \pm 30^{\mathrm{b}}$ & $270.5 \pm 30^{\mathrm{b}}$ & $540.5 \pm 45^{b}$ & $380.9 \pm 20^{b}$ & $105.9 \pm 7^{b}$ & $240.8 \pm 15^{b}$ & $1255.04 \pm 150^{\mathrm{a}}$ \\
\hline
\end{tabular}

a-dMeans within column with different letter(s) indicate significant difference between treatments by Tukey's HSD test at $\mathrm{P} \leq 0.05$. Columns represent the mean values \pm standard error. 
soil available P (Haynes, 1982). Similar observation was made at the end of the second field trial (85 DAS) where the total P and available $P$ recovered under the treatments with the organic amendments (T2 and T3) were significantly higher compared with the non-organic amendments (T0 and T1) (Table 7). This observation is consistent with the findings in the first field trial (75 DAS) and it as well indicates the residual effect of biochar and pineapple leaf residues compost addition in enhancing soil $\mathrm{P}$ availability as $\mathrm{P}$ fertilisers were not applied during the second field trial.

The soluble- $\mathrm{P}_{\mathrm{i}}$ and $\mathrm{Ca}-\mathrm{P}_{\mathrm{i}}$ fractions recovered under the treatments with the organic amendments (T2 and T3) were higher compared with those of the non-organic amendments (T0 and T1) in the first and second field trials (Table 7). This could be partly attributed to the addition of $\mathrm{P}$ through biochar and pineapple leaf residues compost and also due to the effect of the biochar and pineapple leaf residues compost on $\mathrm{P}$ sorption. The decrease in $\mathrm{P}$ sorption is related to the effect of organic acids produced during the decomposition of biochar and pineapple leaf residues compost that might have competed for sorption sites and formation of stable chelates with $\mathrm{Al}$ and $\mathrm{Fe}$ (Laboski and Lamb, 2003). The $\mathrm{P}_{o}$ fraction recovery was significantly higher in the treatments with organic amendments (T2 and T3) compared with those of soil only (T0) or soil and chemical fertilisers only (T1) (Table 7). The increase in $\mathrm{P}_{o}$ with increasing of time is essential because $\mathrm{P}_{o}$ will be mineralised into $\mathrm{P}_{i}$ which is available for plants uptake (Haynes and Mokolobate, 2001).

The Al- $\mathrm{P}_{\mathrm{i}}, \mathrm{Fe}-\mathrm{P}_{\mathrm{i}}$, and reductant soluble- $\mathrm{P}_{\mathrm{i}}$ fractions recovered under T1 (fertilisers) were significantly higher than those of T2 and T3 (fertilisers and organic amendments) at 75 DAS (Table 7). This suggests that the addition of biochar and pineapple leaf residues compost to the soil decreased $\mathrm{P}$ sorption. This was because of the precipitation of exchangeable and soluble $\mathrm{Al}$ and $\mathrm{Fe}$ as insoluble $\mathrm{Al}$ and $\mathrm{Fe}$ hydroxides on the surfaces of the organic amendments (Iyamuremye et al., 1996; Erich et al., 2002). This is evident in the significant reduction of $\mathrm{Al}$ and $\mathrm{Fe}$ through the use of the organic amendments (Table 5). The higher concentrations of $\mathrm{P}$ associated with $\mathrm{Al}\left(\mathrm{Al}-\mathrm{P}_{i}\right)$ and $\mathrm{Fe}\left(\mathrm{Fe}-\mathrm{P}_{i}\right)$ in $\mathrm{T} 1$ (fertilisers) show high exchangeable $\mathrm{Al}$ and extractable $\mathrm{Fe}$ in the soil (Table 7). Similar observation was made during second field trial (85 DAS) (Table 7). The higher recovery of Al- $\mathrm{P}_{\mathrm{i}}, \mathrm{Fe}-\mathrm{P}_{\mathrm{i}}$, and reductant soluble- $\mathrm{P}_{\mathrm{i}}$ under $\mathrm{T} 1$ (fertilisers) compared to $\mathrm{T} 2$ and $\mathrm{T} 3$ (fertilisers and organic amendments) suggests that the organic amendments imposed good residual effect in buffering the soil $\mathrm{pH}$ (Iyamuremye et al., 1996; Erich et al., 2002).

\section{Nutrients uptake, yield of Zea mays L. and phosphorus agronomic efficiency at first and second field trials}

There were significant differences $(\mathrm{P}<0.05)$ in leaves and stems dry weights of maize. The dry weight of leaves and stems were not significantly different in T2 (N-P-K amended with biochar) and T3 (N-P-K amended with pineapple leaf residues compost) in both field trials (Tables 8 and 9). The dry weigh of leaves and stems of T1 (fertilisers) were significantly lower compared with those of T2 and T3 (Tables 8 and 9) suggesting positive

Table 8. Dry weight, $\mathrm{N}, \mathrm{P}, \mathrm{K}, \mathrm{Ca}, \mathrm{Mg}, \mathrm{Na}, \mathrm{Fe}$, and $\mathrm{Al}$ concentrations in leaves and stems of maize hybrid $\mathrm{F} 1$ at harvest in first field trial (75 DAS).

\begin{tabular}{|c|c|c|c|c|c|c|c|c|c|}
\hline Ireatments & $\begin{array}{l}\text { Dry weight } \\
\text { (g) }\end{array}$ & $\begin{array}{c}N \\
(\%)\end{array}$ & $\begin{array}{c}P \\
(\%)\end{array}$ & $\begin{array}{l}\mathrm{K} \\
(\%)\end{array}$ & $\begin{array}{l}\mathrm{Ca} \\
(\%)\end{array}$ & $\begin{array}{l}\text { Mg } \\
(\%)\end{array}$ & $\begin{array}{l}\mathrm{Na} \\
(\%)\end{array}$ & $\begin{array}{l}\mathrm{Fe} \\
(\%)\end{array}$ & $\begin{array}{c}\mathrm{Al} \\
(\mathrm{ppm})\end{array}$ \\
\hline $\begin{array}{l}\text { Leaves } \\
\text { T0 } \\
\text { T1 } \\
\text { T2 } \\
\text { T3 }\end{array}$ & $\begin{array}{c}6.93 \pm 1.5^{\mathrm{c}} \\
23.27 \pm 2.2^{\mathrm{b}} \\
29.22 \pm 2^{\mathrm{a}} \\
28.47 \pm 2^{\mathrm{a}}\end{array}$ & $\begin{array}{c}1.45 \pm 0.2^{\mathrm{d}} \\
2.3 \pm 0.03^{\mathrm{a}} \\
2.15 \pm 0.03^{\mathrm{b}} \\
2 \pm 0.04^{\mathrm{c}}\end{array}$ & $\begin{array}{c}0.1 \pm 0.01^{\mathrm{c}} \\
0.16 \pm 0.01^{\mathrm{b}} \\
0.27 \pm 0.02^{\mathrm{a}} \\
0.26 \pm 0.02^{\mathrm{a}}\end{array}$ & $\begin{array}{l}1.75 \pm 0.03^{\mathrm{c}} \\
2.17 \pm 0.03^{\mathrm{b}} \\
2.44 \pm 0.04^{\mathrm{a}} \\
2.49 \pm 0.06^{\mathrm{a}}\end{array}$ & $\begin{array}{l}0.71 \pm 0.02^{\mathrm{b}} \\
0.75 \pm 0.04^{\mathrm{b}} \\
0.85 \pm 0.03^{\mathrm{a}} \\
0.75 \pm 0.02^{\mathrm{b}}\end{array}$ & $\begin{array}{c}0.18 \pm 0.005^{\mathrm{b}} \\
0.19 \pm 0.01^{\mathrm{b}} \\
0.23 \pm 0.01^{\mathrm{a}} \\
0.22 \pm 0.02^{\mathrm{a}}\end{array}$ & $\begin{array}{c}0.16 \pm 0.005^{\mathrm{b}} \\
0.17 \pm 0.005^{\mathrm{b}} \\
0.21 \pm 0.015^{\mathrm{a}} \\
0.2 \pm 0.01^{\mathrm{a}}\end{array}$ & $\begin{array}{c}0.02 \pm 0.005^{\mathrm{a}} \\
0.014 \pm 0.002^{\mathrm{b}} \\
0.01 \pm 0.002^{\mathrm{c}} \\
0.01 \pm 0.002^{\mathrm{c}}\end{array}$ & $\begin{array}{c}5.51 \pm 0.1^{\mathrm{a}} \\
2.46 \pm 0.1^{\mathrm{b}} \\
1.09 \pm 0.05^{\mathrm{c}} \\
1.14 \pm 0.03^{\mathrm{c}}\end{array}$ \\
\hline $\begin{array}{l}\text { Stems } \\
\text { T0 } \\
\text { T1 } \\
\text { T2 } \\
\text { T3 }\end{array}$ & $\begin{array}{l}14.1 \pm 1.5^{\mathrm{c}} \\
52.42 \pm 4^{\mathrm{b}} \\
88.26 \pm 5^{\mathrm{a}} \\
80.22 \pm 6^{\mathrm{a}}\end{array}$ & $\begin{array}{l}0.43 \pm 0.03^{\mathrm{c}} \\
0.63 \pm 0.02^{\mathrm{a}} \\
0.52 \pm 0.02^{\mathrm{b}} \\
0.51 \pm 0.02^{\mathrm{b}}\end{array}$ & $\begin{array}{c}0.1 \pm 0.01^{\mathrm{d}} \\
0.25 \pm 0.02^{\mathrm{c}} \\
0.41 \pm 0.015^{\mathrm{a}} \\
0.34 \pm 0.02^{\mathrm{b}}\end{array}$ & $\begin{array}{l}0.77 \pm 0.02^{\mathrm{b}} \\
1.14 \pm 0.03^{\mathrm{a}} \\
1.15 \pm 0.04^{\mathrm{a}} \\
1.11 \pm 0.05^{\mathrm{a}}\end{array}$ & $\begin{array}{l}0.24 \pm 0.01^{\mathrm{b}} \\
0.27 \pm 0.02^{\mathrm{b}} \\
0.27 \pm 0.01^{\mathrm{b}} \\
0.32 \pm 0.01^{\mathrm{a}}\end{array}$ & $\begin{array}{c}0.13 \pm 0.005^{\mathrm{c}} \\
0.09 \pm 0.01^{\mathrm{d}} \\
0.16 \pm 0.01^{\mathrm{b}} \\
0.19 \pm 0.01^{\mathrm{a}}\end{array}$ & $\begin{array}{c}0.11 \pm 0.003^{\mathrm{b}} \\
0.08 \pm 0.01^{\mathrm{c}} \\
0.15 \pm 0.02^{\mathrm{a}} \\
0.17 \pm 0.01^{\mathrm{a}}\end{array}$ & $\begin{array}{c}0.016 \pm 0.002^{\mathrm{a}} \\
0.011 \pm 0.001^{\mathrm{b}} \\
0.01 \pm 0.001^{\mathrm{c}} \\
0.01 \pm 0.002^{\mathrm{c}}\end{array}$ & $\begin{array}{c}1.9 \pm 0.1^{\mathrm{a}} \\
0.66 \pm 0.1^{\mathrm{b}} \\
0.37 \pm 0.05^{\mathrm{c}} \\
0.45 \pm 0.3^{\mathrm{c}}\end{array}$ \\
\hline
\end{tabular}

a-dMeans within column with different letter(s) indicate significant difference between treatments by Tukey's HSD test at $\mathrm{P} \leq 0.05$. Columns represent the mean values \pm standard error.

Table 9. Dry weight, $\mathrm{N}, \mathrm{P}, \mathrm{K}, \mathrm{Ca}, \mathrm{Mg}, \mathrm{Na}, \mathrm{Fe}$, and $\mathrm{Al}$ concentrations in leaves and stems of maize hybrid $\mathrm{F} 1$ at harvest in second field trial (85 DAS).

\begin{tabular}{|c|c|c|c|c|c|c|c|c|c|}
\hline Treatments & $\begin{array}{l}\text { Dry weight } \\
\text { (g) }\end{array}$ & $\begin{array}{l}N \\
(\%)\end{array}$ & $\begin{array}{c}\text { P } \\
(\%)\end{array}$ & $\begin{array}{c}\mathrm{K} \\
(\%)\end{array}$ & $\begin{array}{c}\mathrm{Ca} \\
(\%)\end{array}$ & $\begin{array}{l}\mathrm{Mg} \\
(\%)\end{array}$ & $\begin{array}{l}\mathrm{Na} \\
(\%)\end{array}$ & $\begin{array}{l}\mathrm{Fe} \\
(\%)\end{array}$ & $\begin{array}{c}\mathrm{Al} \\
(\mathrm{ppm})\end{array}$ \\
\hline \multicolumn{10}{|l|}{ Leaves } \\
\hline T0 & $4.69 \pm 1.5^{\mathrm{c}}$ & $1.38 \pm 0.02^{\mathrm{c}}$ & $0.08 \pm 0.01^{\mathrm{c}}$ & $0.76 \pm 0.02^{c}$ & $0.62 \pm 0.02^{b}$ & $0.17 \pm 0.01^{b}$ & $0.15 \pm 0.01^{\mathrm{b}}$ & $0.02 \pm 0.0005^{\mathrm{a}}$ & $2.88 \pm 0.06^{\mathrm{a}}$ \\
\hline $\mathrm{T} 1$ & $14.14 \pm 3.5^{b}$ & $2.22 \pm 0.03^{\mathrm{a}}$ & $0.12 \pm 0.01^{b}$ & $1.81 \pm 0.02^{b}$ & $0.65 \pm 0.02^{b}$ & $0.15 \pm 0.01^{b}$ & $0.14 \pm 0.005^{b}$ & $0.018 \pm 0.0005^{b}$ & $1.6 \pm 0.1^{b}$ \\
\hline $\mathrm{T} 2$ & $26.47 \pm 5^{\mathrm{a}}$ & $2.08 \pm 0.04^{\mathrm{ab}}$ & $0.21 \pm 0.01^{\mathrm{a}}$ & $2.19 \pm 0.04^{\mathrm{a}}$ & $0.8 \pm 0.03^{\mathrm{a}}$ & $0.2 \pm 0.02^{\mathrm{a}}$ & $0.18 \pm 0.01^{\mathrm{a}}$ & $0.01 \pm 0.001^{\mathrm{c}}$ & $0.69 \pm 0.05^{c}$ \\
\hline T3 & $22.85 \pm 3^{\mathrm{a}}$ & $1.92 \pm 0.04^{b}$ & $0.21 \pm 0.005^{\mathrm{a}}$ & $2.18 \pm 0.05^{\mathrm{a}}$ & $0.82 \pm 0.02^{\mathrm{a}}$ & $0.19 \pm 0.02^{\mathrm{a}}$ & $0.17 \pm 0.01^{\mathrm{a}}$ & $0.010 \pm 0.0015^{c}$ & $0.84 \pm 0.04^{\mathrm{c}}$ \\
\hline \multicolumn{10}{|l|}{ Stems } \\
\hline TO & $12.21 \pm 2^{\mathrm{c}}$ & $0.4 \pm 0.05^{b}$ & $0.08 \pm 0.01^{\mathrm{d}}$ & $0.68 \pm 0.02^{b}$ & $0.21 \pm 0.01^{\mathrm{a}}$ & $0.12 \pm 0.01^{\mathrm{a}}$ & $0.1 \pm 0.005^{b}$ & $0.02 \pm 0.0005^{\mathrm{a}}$ & $1.52 \pm 0.05^{\mathrm{a}}$ \\
\hline $\mathrm{T} 1$ & $47.01 \pm 4^{b}$ & $0.6 \pm 0.05^{\mathrm{a}}$ & $0.2 \pm 0.02^{\mathrm{c}}$ & $0.94 \pm 0.035^{\mathrm{a}}$ & $0.25 \pm 0.02^{\mathrm{a}}$ & $0.1 \pm 0.01^{\mathrm{a}}$ & $0.07 \pm 0.01^{\mathrm{c}}$ & $0.17 \pm 0.0005^{b}$ & $0.56 \pm 0.03^{b}$ \\
\hline $\mathrm{T} 2$ & $77.29 \pm 5^{\mathrm{a}}$ & $0.48 \pm 0.04^{b}$ & $0.35 \pm 0.02^{\mathrm{a}}$ & $0.98 \pm 0.04^{\mathrm{a}}$ & $0.26 \pm 0.02^{\mathrm{a}}$ & $0.11 \pm 0.01^{\mathrm{a}}$ & $0.13 \pm 0.01^{\mathrm{a}}$ & $0.01 \pm 0.0015^{c}$ & $0.4 \pm 0.04^{b}$ \\
\hline T3 & $73.03 \pm 4^{a}$ & $0.48 \pm 0.03^{b}$ & $0.29 \pm 0.02^{b}$ & $1.02 \pm 0.05^{\mathrm{a}}$ & $0.29 \pm 0.02^{\mathrm{a}}$ & $0.13 \pm 0.02^{a}$ & $0.14 \pm 0.015^{a}$ & $0.01 \pm 0.001^{\mathrm{c}}$ & $0.5 \pm 0.06^{b}$ \\
\hline
\end{tabular}

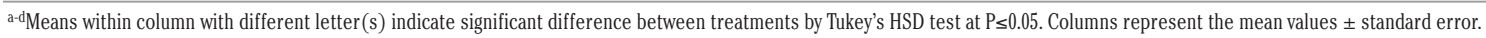


effect of combining organic amendments and inorganic fertilisers on growth of maize plants. This combination ensured timely release of nutrients in the soil which explains the similar observations obtained during second field trial (Lal and Stewart, 2014). The total $\mathrm{N}$ concentrations in leaves and stems were lower in $\mathrm{T} 2$ and T3 (fertilisers and organic amendments) in the first field trial (75 DAS) (Table 9). This could be due to the distribution of the $\mathrm{N}$ into other parts of the maize plant because the treatments with organic amendments (T2 and T3) showed higher dry weight compared to the treatments with chemical fertilisers only (T1) and soil only (T0). In terms of $\mathrm{N}$ uptake in leaves and stems, the treatments with organic amendments (T2 and T3) significantly improved N uptake compared with T1 (fertilisers) (Table 10) and this indicates that there was less $\mathrm{N}$ loss from the soil-plant system. This may be attributed to slow release of $\mathrm{N}$ from the organic amendments such that the $\mathrm{N}$ released was in synchrony with the demand of the maize plant. The urea used in this study without any of the organic amendments (T1) might have also released $\mathrm{N}$ too fast and too early in the maize growing season before the maize crop developed an extensive root system to take it up. Some of the available $\mathrm{N}$ in the soil might have been lost through volatilisation and denitrification or the urea-N might have been immobilised into forms not readily available to the plants, thus the lower $\mathrm{N}$ uptake in T1. However, the total $\mathrm{N}$ concentrations in leaves did not differ significantly between T1 (chemical fertilisers only) and treatments with organic amendments (T2 and T3) during second field trial (85 DAS) (Table 9). In terms of $\mathrm{N}$ uptake in leaves and stems, the treatments with organic amendments (T2 and T3) significantly improved N uptake compared with T1 (chemical fertilisers only) (Table 11). This is consistent with that of the first field trial. The $\mathrm{P}$ and $\mathrm{K}$ concentrations
(Tables 8 and 9) and uptakes (Tables 10 and 11) in leaves and stems of maize in both field trials were significantly higher when the organic amendments were added with chemical fertilisers. The addition of organic amendments in the soil increased soil $\mathrm{pH}$ and reduced soil exchangeable $\mathrm{Al}$ and extractable $\mathrm{Fe}$, thus reduced the risk of Al toxicity in the roots. This could have improved better root growth in the maize plants which received the organic amendments (T2 and T3), hence the increased $\mathrm{P}$ and $\mathrm{K}$ uptake in maize. Similarly, total $\mathrm{Ca}, \mathrm{Mg}$, and $\mathrm{Na}$ concentrations (Tables 8 and 9) and uptakes (Tables 10 and 11) in the leaves and stems of the maize plants under the application of organic amendments increased compared with the treatments without any organic amendments (T0 and T1). This was because of the higher contents of these cations in the treatments with organic amendments (T2 and T3) compared with the treatments without any organic amendments (T0 and T1). Addition of these basic cations to soil contributed to soil acidity regulation and binding of exchangeable $\mathrm{Al}$ and extractable $\mathrm{Fe}$ in the soil, thus the increasing the availability of plant nutrients and enhancing nutrients uptake at the rooting zone. At the end of first and second field trials, total $\mathrm{Al}$ and Fe were significantly reduced in the leaves and stems of the maize plants grown on the soil with the organic amendments (T2 and T3) (Tables 8 and 9). This improvement is attributed to the general improvement of the soil environment (in terms of increasing the soil $\mathrm{pH}$ and the chelation of exchangeable $\mathrm{Al}$ and $\mathrm{Fe}$ by the organic amendments). Treatments with the organic amendments (T2 and T3) increased the maize cob and grains compared to the treatments without any organic amendments (T0 and T1) in both field trials (Table 12). The combination of organic amendments and chemical fertilisers (T2 and T3) is beneficial because this approach balances

Table 10. Total $\mathrm{N}, \mathrm{P}, \mathrm{K}, \mathrm{Ca}, \mathrm{Mg}, \mathrm{Na}, \mathrm{Fe}$, and $\mathrm{Al}$ uptakes in leaves and stems of maize hybrid $\mathrm{F} 1$ at harvest in first field trial (75 $\mathrm{DAS}$ ).

\begin{tabular}{|c|c|c|c|c|c|c|c|c|}
\hline Treatments & $\mathbf{N}$ & $\mathbf{P}$ & Kotal t & $\begin{array}{c}\mathrm{Ca} \\
\text { take (mg }\end{array}$ & $\begin{array}{c}\mathrm{Mg} \\
\left.\text { ant }^{-1}\right)\end{array}$ & $\mathrm{Na}$ & $\mathrm{Fe}$ & Al ( 1 g plant $\left.{ }^{-1}\right)$ \\
\hline \multicolumn{9}{|l|}{ Leaves } \\
\hline TO & $100.49 \pm 3.5^{\mathrm{d}}$ & $6.93 \pm 1^{\mathrm{c}}$ & $121.75 \pm 10^{c}$ & $49.2 \pm 3^{\mathrm{d}}$ & $12.47 \pm 2^{\mathrm{c}}$ & $11.1 \pm 1^{\mathrm{c}}$ & $1.39 \pm 0.1^{\mathrm{c}}$ & $3.81 \pm 0.1^{\mathrm{b}}$ \\
\hline $\mathrm{T} 1$ & $535.21 \pm 12^{c}$ & $37.23 \pm 2^{b}$ & $504.96 \pm 12^{\mathrm{b}}$ & $174.53 \pm 5^{c}$ & $44.21 \pm 3.5^{b}$ & $39.6 \pm 2^{b}$ & $2.33 \pm 0.35^{b}$ & $5.72 \pm 0.35^{\mathrm{a}}$ \\
\hline $\mathrm{T} 2$ & $628.23 \pm 14^{\mathrm{a}}$ & $78.89 \pm 3^{\mathrm{a}}$ & $712.97 \pm 10^{\mathrm{a}}$ & $248.37 \pm 5^{\mathrm{a}}$ & $67.21 \pm 5^{\mathrm{a}}$ & $61.36 \pm 4^{\mathrm{a}}$ & $2.92 \pm 0.3^{\mathrm{a}}$ & $3.18 \pm 0.35^{b}$ \\
\hline $\mathrm{T} 3$ & $569.4 \pm 15^{\mathrm{b}}$ & $74.02 \pm 2^{\mathrm{a}}$ & $708.9 \pm 5^{\mathrm{a}}$ & $213.53 \pm 10^{\mathrm{b}}$ & $62.63 \pm 5.5^{\mathrm{a}}$ & $56.94 \pm 5.5^{\mathrm{a}}$ & $2.85 \pm 0.25^{\mathrm{a}}$ & $3.98 \pm 0.4^{b}$ \\
\hline \multicolumn{9}{|l|}{ Stems } \\
\hline T0 & $60.63 \pm 3.5^{\mathrm{d}}$ & $14.1 \pm 1^{d}$ & $108.57 \pm 5^{\mathrm{d}}$ & $33.84 \pm 2^{\mathrm{c}}$ & $18.33 \pm 2^{c}$ & $15.5 \pm 1.5^{\mathrm{c}}$ & $1.41 \pm 0.4^{c}$ & $2.68 \pm 0.4^{b}$ \\
\hline $\mathrm{Tl}$ & $330.25 \pm 10^{c}$ & $131.05 \pm 4^{c}$ & $597.59 \pm 10^{c}$ & $141.53 \pm 5^{b}$ & $47.18 \pm 3.5^{b}$ & $41.94 \pm 2.5^{b}$ & $5.24 \pm 0.5^{b}$ & $3.46 \pm 0.2^{\mathrm{a}}$ \\
\hline $\mathrm{T} 2$ & $458.95 \pm 8^{\mathrm{a}}$ & $361.86 \pm 5.5^{\mathrm{a}}$ & $1014.99 \pm 10^{\mathrm{a}}$ & $238.3 \pm 5^{\mathrm{a}}$ & $141.22 \pm 4^{\mathrm{a}}$ & $132.4 \pm 4^{\mathrm{a}}$ & $8.83 \pm 0.3^{\mathrm{a}}$ & $3.26 \pm 0.2^{\mathrm{a}}$ \\
\hline T3 & $409.12 \pm 5^{b}$ & $272.75 \pm 5^{\mathrm{b}}$ & $890.44 \pm 20^{b}$ & $256.7 \pm 6^{\mathrm{a}}$ & $152.42 \pm 5^{\mathrm{a}}$ & $136.4 \pm 5^{\mathrm{a}}$ & $8.02 \pm 0.4^{\mathrm{a}}$ & $3.61 \pm 0.2^{\mathrm{a}}$ \\
\hline
\end{tabular}

a-dMeans within column with different letter(s) indicate significant difference between treatments by Tukey's HSD test at $P \leq 0.05$. Columns represent the mean values \pm standard error.

Table 11. Total N, P, K, Ca, Mg, Na, Fe, and Al uptakes in leaves and stems of maize hybrid F1 at harvest in second field trial (85 DAS).

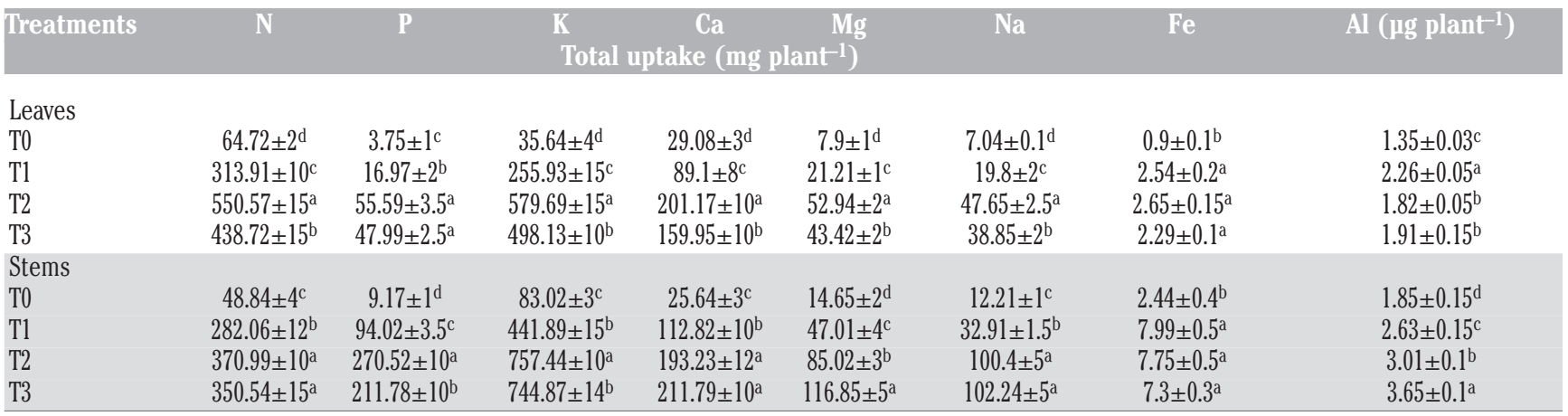

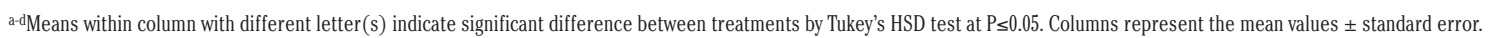


Table 12. Effects of treatments on maize hybrid F1 yield and phosphorus agronomic efficiency, in the two field trials.

\begin{tabular}{|c|c|c|c|}
\hline Treatments & Cob (tonnes ha-1) & Grain $\left(\mathrm{n}^{\circ} \mathrm{cob}^{-1}\right)$ & Phosphorus agronomic efficiency (\%) \\
\hline $\begin{array}{l}\text { First field trial (75 DAS) } \\
\text { T0 } \\
\text { T1 } \\
\text { T2 } \\
\text { T3 }\end{array}$ & $\begin{array}{c}2.7 \pm 0.3^{\mathrm{c}} \\
6.3 \pm 1.5^{\mathrm{b}} \\
14.6 \pm 1.3^{\mathrm{a}} \\
15.8 \pm 2.4^{\mathrm{a}}\end{array}$ & $\begin{array}{l}321 \pm 30^{\mathrm{c}} \\
356 \pm 65^{\mathrm{b}} \\
790 \pm 75^{\mathrm{a}} \\
765 \pm 80^{\mathrm{a}}\end{array}$ & $\begin{array}{c}- \\
60.3 \pm 2^{\mathrm{b}} \\
197.7 \pm 5^{\mathrm{a}} \\
208.3 \pm 7^{\mathrm{a}}\end{array}$ \\
\hline $\begin{array}{l}\text { Second field trial (85 DAS) } \\
\text { T0 } \\
\text { T1 } \\
\text { T2 } \\
\text { T3 }\end{array}$ & $\begin{array}{c}1.3 \pm 0.2^{\mathrm{d}} \\
8.5 \pm 0.3^{\mathrm{c}} \\
10.4 \pm 1.4^{\mathrm{a}} \\
9.3 \pm 0.3^{\mathrm{b}}\end{array}$ & $\begin{array}{l}154 \pm 40^{\mathrm{c}} \\
351 \pm 55^{\mathrm{b}} \\
563 \pm 70^{\mathrm{a}} \\
555 \pm 60^{\mathrm{a}}\end{array}$ & $\begin{array}{c}- \\
108.63 \pm 6^{\mathrm{c}} \\
150.5 \pm 40^{\mathrm{a}} \\
133.1 \pm 45^{\mathrm{b}}\end{array}$ \\
\hline
\end{tabular}

a-dMeans within column with different letter(s) indicate significant difference between treatments by Tukey's HSD test at $\mathrm{P} \leq 0.05$. Columns represent the mean values \pm standard error.

release of nutrients and it as well ensures reduction of $\mathrm{N}, \mathrm{P}$, and $\mathrm{K}$ loss (Liu et al., 2008). Kimeto et al. (2004) also found that combination of organic and inorganic nutrient sources gave higher maize yield than when each was applied separately. In a similar study, Zhao et al. (2009) also found that combination of farmyard manure and chemical fertilisers management increased maize yield, soil organic matter, available $\mathrm{N}$, and available $\mathrm{P}$ compared with those found under mineral fertiliser treatments. The significant increase in maize cob and grain yields with application of organic amendments (T2 and T3) was also due to the improvement of the soil chemical properties such as decrease in acidity, increased availability of plant nutrients and enhanced microbial activities especially at the rhizosphere. Application of organic amendments and chemical fertilisers (T2 and T3) significantly increased the agronomic efficiency of $\mathrm{P}$ applied to the soils compared with chemical fertilisers only in both field trials (Table 12). This is consistent with the interactive effect of the organic amendments with chemical fertilisers which resulted in the increased $\mathrm{P}$ uptake by the maize plants. The humic substances of the organic amendments are responsible for buffering the soil $\mathrm{pH}$. Increase in $\mathrm{pH}$ of soils with high exchangeable acidity tends to increase plant $\mathrm{P}$ uptake. This is related to improved root growth due to mitigation of Al toxicity, thus allowing a greater volume of soil for root elongation. The treatments of chemical fertilisers with the organic amendments (T2 and T3) significantly increased the agronomic efficiency of the P applied to the soils compared with chemical fertilisers only (T1) suggests an interactive effect of organic amendments together with chemical fertilisers in enhancing P uptake of maize plants.

\section{Conclusions}

The results of the present study suggest that the organic amendments (chicken litter biochar and pineapple leaf residues compost) can increase availability of $\mathrm{N}, \mathrm{K}, \mathrm{Ca}$, and $\mathrm{Mg}$ in the soil. They can also increase soil $\mathrm{pH}$ to near neutral such that the soil's exchangeable $\mathrm{Al}$ and extractable Fe which normally fix soil $\mathrm{P}$ are reduced. As a result, $\mathrm{P}$ availability (total $\mathrm{P}$, available $\mathrm{P}$, inorganic $\mathrm{P}$ fractions, and organic $\mathrm{P}$ ) in the soil increased. Additionally, the organic amendments can also improve Zea mays L. nutrient uptake, yield, and $\mathrm{P}$ agronomic efficiency. The findings of this study further suggest that amending chemical fertilisers with organic amendments have a larger residual effect than chemical fertilisers only and can be used to ameliorate $\mathrm{P}$ fixation and improve maize production in acid soils.

\section{References}

Adnan A, Mavinic DS, Koch FA, 2003. Pilot-scale study of phosphorus recovery through struvite crystallisation-examining to process feasibility. J. Environ. Engin. Sci. 2:315-24.

Akande MO, Oluwatoyinbo FI, Adediran FA, Buari KW, Yusuf IO, 2003. Soil amendments affect the Release of $P$ from rock phosphate and the development and Yield of Okra. J. Vege. Crop. Product. 19:3-9.

Bauder JW, Brock TA, 2001. Irrigation water quality, soil amendment, and crop effects on sodium leaching. Arid Land Res. Manage. 15:101-13.

Blackwell P, Riethmuller G, Collins M, 2009. Biochar application to soil. In: Biochar for Environmental Management: Science and Technology. Earthscan, London, UK, pp 207-26.

Bouyoucos GJ, 1962. Hydrometer meter improved for making particle size analysis of soils. Agron. J. 54:464-5.

Brady NC, Weil RR, 2002. The nature and properties of soils, 13th edition. Pearson Education Inc., New Jersey, USA.

Ch'ng, HY, Ahmed OH, Kasim S, Majid NMA, 2013. Co-composting of pineapple leaves and chicken manure slurry. Int. J. Recycl. Org. Waste Agric. 2:1-7.

Ch'ng HY, Ahmed OH, Majid NMA, 2014. Biochar and compost influence the phosphorus availability, nutrient uptake, and growth of maize (Zea mays L.) in tropical acid soil. Pak. J. Agric. Sci. 51:797-806.

Ch'ng HY, Ahmed OH, Majid NMA, 2015. Improving phosphorus availability, nutrient uptake and dry matter production of Zea mays L. on a tropical acid soil using poultry manure biochar and pineapple leaves compost. Exp. Agric. 52:447-65.

Cottenie A, 1980. Soil testing and plant testing as a basis of fertilizer recommendation. FAO Soil Bull. 38:70-3.

Eghball B, 2002. Soil properties as influenced by phosphorus and nitrogen - based manure and compost applications. Agron. J. 94:128-35.

Enwezor WO, Udo EJ, Usoroh NJ, Ayotade KA, Adepetu JA, Chude VO, Udegbe CI, 1989. Fertiliser use and management practices for crop in Nigeria (Series No. 2). Produced by the fertiliser procurement and distribution division of the Federal Ministry of Agriculture Water Resources and Rural Development, Lagos, Nigeria.

Erich MS, Fitzgerald CB, Porter GB, 2002. The effect of organic amendment on phosphorus chemistry in a potato cropping system. Agric. Ecosys. Environ. 88:79-88.

Guppy CN, Menzies NW, Moody PW, Blamey FPC, 2005. Competitive sorption reactions between phosphorus and 
organic matter in soil: a review. Aust. J. Soil Res. 43:189-202.

Haynes R, 1982. Effects of liming on phosphate availability in acid soils. Plant Soil. 68:289-308.

Haynes RJ, Mokolobate MS, 2001. Amelioration of Al toxicity and $P$ deficiency in acid soils by additions of organic residues: a critical review of the phenomenon and the mechanism involved. Nutr. Cycl. Agroecosys. 59:47-63.

Hue NV, 1990. Interaction of $\mathrm{Ca}\left(\mathrm{H}_{2} \mathrm{PO}_{4}\right)_{2}$ applied to an Oxisol and previous sludge amendment: soil and crop response. Commun. Soil Sci. Plant Anal. 21:61-73.

Hue NV, Craddock GR, Adams F, 1986. Effects of organic acids on aluminium toxicity in subsoil. Soil Sci. Soc. Am. J. 25:3291-303.

Hue NV, Ikawa H, Silva JA, 1994. Increasing plant-available phosphorus in an Ultisol with a yard-waste compost. Commun. Soil Sci. Plant Anal. 25:3291-303.

Iyamuremye F, Dick RP, Baham J, 1996. Organic amendments and phosphorus dynamics: 1. Phosphorus chemistry and sorption. Soil Sci. 161:426-35.

Kaschl A, Romheld V, Chen Y, 2002. The influence of soluble organic matter from municipal solid waste compost on trace metal leaching in calcareous soils. Sci. Total Environ. 291:45-57.

Kimeto JM, Mugendi DN, Palm CA, Mutuo PK, Gachengo C, Bationo A, Nandwa S, Kungu JB, 2004. Nitrogen fertiliser equivalencies of organics of differing quality and optimum combination with inorganic nitrogen source in Central Kenya. Nutr. Cycl. Agroecosys. 68:127-35.

Kuo S, 1996. Phosphorus. In: Methods of soil analysis 3; Chemical methods. Soil Science Society of America, Madison, WI, USA, pp 869-919.

Laboski CAM, Lamb JA, 2003. Changes in soil test phosphorus concentration after application of manure or fertiliser. Soil Sci. Soc. Am. J. 67:544-54.

Lal R, Stewart BA, 2014. Soil management of smallholder agriculture. CRC Press, Boca Raton, FL, USA, pp 260.

Liu J, Xie Q, Shi Q, Li M, 2008. Rice uptake and recovery of nitrogen with different methods of applying ${ }^{15} \mathrm{~N}$-labeled chicken manure and ammonium sulphate. Plant Product. Sci. 11:271-7.

Malaysia Agricultural Research and Development Institute (MARDI), 1993. Jagung manis baru (new sweet corn): masmadu. MARDI, Kuala Lumpur, Malaysia.

Meeuwissen PC, 1992. Champost can good concurrent met mestsoorten. Champignon Cult. 36:95-101.

Morais FA, Gatiboni LC, 2015. Phosphorus availability and microbial immobilisation in a Nitisol with the application of mineral and organo-mineral fertilisers. An. Acad. Bras. Cienc. 2015:1-11.

Murphy J, Riley JJ, 1962. A modified single solution method for the determination of phosphate in natural waters. Anal. Chim. Acta 27:31-6

Narambuye FX, Haynes RJ, 2006. Effect of organic amendments on soil $\mathrm{pH}$ and $\mathrm{Al}$ solubility and use of laboratory indices to predict their liming effect. Soil Sci. 17110:754-63.

Neill C, Piccolo MC, Cerri CC, Steudler PA, Melillo JM, Brito M, 1997. Net nitrogen mineralisation and net nitrification rates in soils following deforestation for pasture across the southwestern Brazilian Amazon Basin landscape. Oeeologia 110:243-52.

Noble AD, Zenneck I, Randall PJ, 1996. Leaf litter ash alkalinity and neutralisation of soil acidity. Plant Soil 179:293-302.

Novak JM, Busscher WJ, Laird DL, Ahmedna M, Watts DM, Niandou MAS, 2009. Impact of Biochar Amendment on Fertility of a Southeastern Coastal Plain Soil. Soil Sci. 174:105-12.
Ohno T, Amirbahma A, 2010. Phosphorus availability in boreal forest soils: a geochemical and nutrient uptake modeling approach. Geoderma 155:46-54.

Ohno T, Fernandez IJ, Hiradate S, Sherman JF, 2007. Effects of soil acidification and forest type on water soluble soil organic matter properties. Geoderma 140:176-87.

Opala PA, Okalebo JR, Othieno CO, 2012. Effects of organic and inorganic materials on soil acidity and phosphorus availability in a soil incubation study. ISRN Agron. 597216:1-10.

Paulin B, Malley PO, 2008. Compost production and use in horticulture. Department of Agriculture and Food, Government of Western Australia.

Peech HM, 1965. Hydrogen-ion activity. In: Methods of soil analysis, part 2. American Society of Agronomy, Madison, WI, USA.

Rahman ZA, Gikonyo E, Silek B, Goh KJ, Soltangheis A, 2014. Evaluation of phosphate rock sources and rate of application on oil palm yield grown on peat soils of Sarawak, Malaysia. J. Agron. 13:12-22.

Ramamurthy V, Shivashankar K, 1996. Residual effect of organic matter and phosphorus on growth, yield and quality of maize (Zea mays). Indian J. Agron. 41:247-51.

Ritchie GSP, 1994. Role of dissolution and precipitation of minerals in controlling soluble aluminium in acidic soils. Adv. Agron. 53:47-83.

Rivaie AA, Loganathan P, Graham JD, Tillman RW, Payn TW, 2008. Effect of phosphate rock and triple superphosphateon soil phosphorus fractions and their plant-availability and downward movement in two volcanic ash soils under Pinus radiata plantations in New Zealand. Nutr. Cycl. Agroecosyst. 82:75-88.

Rowell DL, 1994. Soil science: methods and applications. Prentice Hall, London, UK.

Schollenberger CJ, Dreibelbis FR, 1945. Determination of exchange capacity and exchangeable bases in soil Ammonium acetate method. Soil Sci. 59:13-24.

Snyder CS, Bruulsema TW, 2007. Nutrient use efficiency and effectiveness in North America: Indices of agronomic and environmental benefit. June 2007, Reference \# 07076. International Plant Nutrition Institute, Norcross, GA, USA,pp 4.

Tan KH, 2003. Soil sampling, preparation and analysis. Taylor \& Francis Inc., New York, NY, USA.

Tang C, Sparling GP, McLay CDA, Raphael C, 1999. Effect of short-term legume residue decomposition on soil acidity. Aust. J. Soil Res. 237:561-73.

Wong MTF, Nortcliff S, Swift RS, 1998. Method for determining the acid ameliorating capacity of plant residue compost, urban waste compost, farmyard manure, and peat applied to tropical soils. Commun. Soil Sci. Plant Anal. 29:2927-37.

Yao Y, Gao B, Zhang M, Inyang M, Zimmerman N, 2012. Effect of biochar amendment on sorption and leaching of nitrate, ammonium, and in a sandy soil. Chemosphere 89:1467-71.

Yazdanpanah N, Pazira E, Neshat A, Mahmoodabadi M, Sinobas LR, 2013. Reclamation of calcareous saline sodic soil with different amendments (II): Impact on nitrogen, phosphorous and potassium redistribution and on microbial respiration. Agric. Water Manage. 120:39-45.

Zhao Y, Wang P, Li J, Chen Y, Ying X, Liu S, 2009. The effect of two organic manures on soil properties and crop yields on a temperate calcareous soil under a wheat-maize cropping system. Eur. J. Agron. 31:36-42. 